\title{
Efektifitas Ekstrak Tanaman Meniran (Phyllanthus niruri) Sebagai Antibakteri Edwardsiella tarda Secara In Vitro
}

\section{Effectivity Of Meniran (Phyllanthus niruri) Extract as Edwardsiella tarda Antibacterial According In Vitro}

\author{
Sudarno, Fabi Aisah Setiorini dan Hari Suprapto
}

Fakultas Perikanan dan Kelautan Universitas Airlangga

Kampus C Mulyorejo - Surabaya, 60115 Telp. 031 - 5911451

\begin{abstract}
Medicinal plants proven to effectively cope with bacterial diseases one of which is the plant meniran (Phyllanthus niruri). Phyllanthus niruri can act as an antibacterial because it has an antibacterial ingredient content of flavonoids, alkaloids, phenols, and tannins. This shows that plants can be used as an antibacterial Phyllanthus niruri of E.tarda. The purpose of this study was to determine the ability of the antibacterial of Phyllanthus niruri extracts and to find out the best concentration of Phyllanthus niruri extracts as antibacterial E.tarda according in vitro. The experiment was conducted in January 2011, housed at the Laboratory of Bacteriology Juanda Fish Quarantine Center and Laboratory of Organic Chemistry and Technology Faculty of Airlangga University Saints. This research method is done by the Minimum Inhibitor Concentration (MIC) and Minimum Bacterial Concentration (MBC) with 12 treatment. The results showed that the best concentration for the treatment of the concentration of $0.0313 \mathrm{~g} / \mathrm{ml}$ as indicated with no growth of bacteria and is the lowest concentration of the dilution.
\end{abstract}

Keywords : Phyllanthus niruri, antibacterial, the best consentration.

\section{Pendahuluan}

Indonesia merupakan negara tropis yang memiliki kekayaan beragam jenis tanaman yang berpotensi sebagai obat. Penggunaan tanaman sebagai obat memiliki beberapa keuntungan yaitu bahan alami pengganti antibiotik, ramah terhadap lingkungan, tidak menyebabkan resistensi pada ikan, mudah diperoleh dan harganya ekonomis. Tanaman obat terbukti efektif mengatasi penyakit bakteri salah satunya yaitu tanaman meniran (Phyllanthus niruri). Tanaman meniran dapat berfungsi sebagai antibakteri karena memiliki kandungan bahan antibakteri yaitu flavonoid, alkaloid, fenol, dan tanin (Sidik dan Subarnas, 1993). Hal ini menunjukkan bahwa tanaman meniran dapat digunakan sebagai antibakteri E.tarda.

Bakteri E.tarda merupakan salah satu penyakit ikan yang disebabkan oleh bakteri. Bakteri E.tarda dikenal sebagai penyakit pada budidaya ikan lele (Leotta, et al., 2009). Bakteri E.tarda memiliki habitat pada perairan tawar dan laut yang mengandung bahan-bahan organik serta berlumpur (Afrianto dan Liviawaty, 1992). Bakteri E.tarda merupakan bakteri yang dapat tumbuh optimal pada suhu $25-30^{\circ} \mathrm{C}$ dan pada suhu kurang dari $10^{\circ} \mathrm{C}$ serta pada suhu lebih dari $45^{\circ} \mathrm{C}$ bakteri ini tidak dapat tumbuh. Bakteri E.tarda menyebabkan luka pada ikan yang terinfeksi karena bakteri ini memproduksi exotoksin (Rao, et al., 2004). Bakteri E.tarda menyebabkan beberapa gejala klinis yaitu pada infeksi ringan yang ditandai dengan luka kecil kemudian berkembang menjadi luka yang bernanah, Pada infeksi berat dapat meyebabkan luka bernanah yang bertambah secara cepat dengan berbagai ukuran. Pada infeksi berat luka bernanah tersebut berisi gas dan dapat menyebar ke seluruh tubuh serta jika luka tersebut digores maka akan tercium bau busuk yang diakibatkan kandungan $\mathrm{H}_{2} \mathrm{~S}$ pada luka tersebut (Health Agency, 2001).

Penanggulangan penyakit yang disebabkan oleh E.tarda pada umumnya menggunakan obat-obatan. Penggunaan obat-obatan mempunyai dampak negatif, salah satunya adalah pencemaran pada tempat hidup ikan. Salah satu alternatif penanggulangan penyakit ikan yang aman adalah dengan menggunakan tanaman obat, oleh karena itu penelitian ini penting untuk dilakukan.

\section{Materi dan Metode}

Identifikasi Bakteri

Isolat bakteri E.tarda ATCC 15947 yang didapat di Balai Karantina Ikan Juanda, diidentifikasi dilakukan dengan melihat morfologi koloni pada TSA, uji gram, O/F, uji oksidase, uji katalase, uji motilitas, produksi indol, LIA, ornithin, simmon sitrate, arginin, urease, MR/VP, TSIA dan uji gulagula. 
Penyiapan Suspensi Bakteri

Suspensi bakteri yang akan digunakan terlebih dahulu disetarakan dengan larutan standar Mc Farland 1. Cara penyetaraannya yaitu pengenceran dengan 4 tabung yang berisi aquades. Pada tabung pertama berisi $10 \mathrm{ml}$ dan 2-3 ose bakteri kemudian divortex, pada tabung kedua hingga tabung keempat berisi $9 \mathrm{ml}$ aquades. Penyetaraan dilakukan dari tabung pertama yang berisi $10 \mathrm{ml}$ aquades dan 23 ose bakteri dimbil $1 \mathrm{ml}$ untuk di masukkan pada tabung kedua, pada tabung kedua diambil $1 \mathrm{ml}$ untuk dimasukkan pada tabung ketiga, pada tabung ketiga diambil $1 \mathrm{ml}$ kemudian dimasukkan pada tabung keempat. Sebelum diambil $1 \mathrm{ml}$ untuk diberikan pada tabung berikutnya tabung divortex dahulu agar homogen. Setelah semua tabung selesai dilakukan pengenceran kemudian disetarakan dengan Mc.Farland 1 dengan melihat pengenceran yang setara dengan Mc.farland 1.

Pembuatan Ekstrak Meniran

Pada metode ekstraksi dilakukan dengan tiga tahapan yaitu maserasi, penyaringan dan penguapan. Pada tahap maserasi bahan-bahan kering pada ekstrak direndam hari dalam pot besar kemudian ditambah pelarut selama tiga hari. Kemudian dilanjutkan dengan tahap penyaringan dengan kertas saring. Pada tahap terakhir hasil penyaringan diuapkan dengan menggunakan alat rotary vacuum evaporator. Ekstrak yang dihasilkan setelah penguapan yaitu 70 gr ektrak kental.

\section{Minimum Inhibitor Concentration (MIC)}

Minimum Inhibitory Concentration (MIC)

adalah pengujian untuk menentukan dosis terendah yang dapat membunuh patogen dengan jumlah paling tinggi. Obat yang paling baik adalah yang memiliki tingkat efektifitas yang tinggi artinya dapat membunuh patogen dalam jumlah besar tetapi tidak membahayakan ikan. Penelitian ini menggunakan metode pengenceran yaitu dengan cara pengenceran secara bertingkat. Penelitian dengan MIC dilakukan melalui beberapa tahap yang diawali dengan menyiapkan medium 10 tabung. Pada tabung kontrol positif diisi dengan $1 \mathrm{ml}$ aqudes dan $1 \mathrm{ml}$ suspensi bakteri dan pada kontrol negatif berisi 1 gr ekstrak meniran dan $1 \mathrm{ml}$ aquades. Pada tabung pertama diisi dengan 1 gr ekstrak meniran kemudian pada tabung kedua diisi dengan $1 \mathrm{ml}$ aquades dan 1 gr ekstrak meniran, pada tabung ketiga berisi $1 \mathrm{ml}$ aquades dan 1 gr ekstrak meniran yang berasal dari tabung kedua kemudian dihomogenkan,dan seterusnya hingga pada tabung kesepuluh dengan perlakuan yang sama. Pada tabung kesepuluh pengenceran dibuang $1 \mathrm{ml}$. Suspensi bakteri dimasukkan sebanyak $1 \mathrm{ml}$ pada masing-masing tabung dari tabung satu hingga tabung kesepuluh yang telah disetarakan dengan Mc Farland 1 dengan kepadatan suspensi bakteri $10^{8}$ CFU/ml, kemudian seluruh tabung divortex dan diinkubasi pada laminar flow selama 24 jam. Setelah 24 jam dilakukan pengamatan terhadap kekeruhan pada larutan pada tabung dengan secara visual.

\section{Minimum Bacterial Concentration (MBC)}

Setelah dilakukan uji MIC kemudian dilanjutkan dengan melakukan uji MBC untuk mengetahui pertumbuhan dari bakteri pada media pengenceran. Pada metode MBC ini dilakukan dengan cara mengambil satu ose dari tabung pertama kemudian diinokulasi pada media TSA dalam petridish. Inokulasi dilakukan pada masing-masing tabung. Setelah semua telah dilakukan inokulasi kemudian diinkubasi pada laminar flow selama 24 jam. Setelah 24 jam diamati pertumbuhan bakteri pada media inokulan yaitu media TSA. Apabila terdapat pertumbuhan bakteri berarti meniran tidak dapat membunuh bakteri pada konsentrasi tersebut sedangkan apabila tidak terdapat bakteri berarti ekstrak meniran dapat membunuh pada konsentrasi tersebut.

\section{Hasil dan Pembahasan}

Hasil Identifikasi Bakteri

Identifikasi bakteri dengan tujuan untuk mengetahui apakah biakan murni adalah E.tarda. Identifikasi yang dilakukan yaitu dengan melihat morfologi, pewarnaan gram dan uji biokimia seperti Oksidase, Katalase, O/F, Motilitas, Indole, $\mathrm{H}_{2} \mathrm{~S}$, $\mathrm{MR} / \mathrm{Vp}$, Citrate, Urease LIA, Arginin, Ornithin, Gula. Hasil pada identifikasi pada E.tarda dapat dilihat pada Tabel 1 
Tabel 1. Hasil Identifikasi Bakteri E. Tarda

\begin{tabular}{|c|c|c|c|}
\hline Parameter & Hasil & Parameter & Hasil \\
\hline Koloni pada TSA & & Uji Biokimia & \\
\hline - Warna koloni & Putih & - Oksidase & - \\
\hline - Tepi koloni & Rata & - Katalase & + \\
\hline - Elevasi koloni & Cembung & $\cdot \mathrm{O} / \mathrm{F}$ & $\mathrm{F}$ \\
\hline \multirow[t]{2}{*}{ - Struktur dalam koloni } & Transparan & - $\mathrm{H}_{2} \mathrm{~S}$ & + \\
\hline & & - $\mathrm{MR} / \mathrm{Vp}$ & $+/-$ \\
\hline Uji Gula & & - Citrate & - \\
\hline - Arabinosa & - & - Urease & - \\
\hline - Manitol & - & $\bullet$ LIA & - \\
\hline - Sukrose & - & - Arginin & + \\
\hline - Glukosa & + & - Omithin & + \\
\hline - Laktosa & - & • TSIA & $\mathrm{K} / \mathrm{A}, \mathrm{H}_{2} \mathrm{~S}$, gas \\
\hline - Inositol & - & & \\
\hline \multirow[t]{3}{*}{ - Maltose } & + & Secara Mirkoskopik & \\
\hline & & • Bentuk bakteri & Batang \\
\hline & & • Pewarnaan gram & Negatif \\
\hline
\end{tabular}

Hasil Uji Efektifitas Tanaman Meniran Terhadap Bakteri E. Tarda

Hasil Uji MIC (Minimum Inhibitor Concentration)

Uji MIC merupakan suatu cara untuk menentukan konsentrasi terendah dari bahan-bahan yang digunakan sebagai obat (ekstrak meniran) sehingga dapat membunuh pertumbuhan dari E.tarda secara visual (Ardiansyah, 2007). Indikator pada pengujian MIC yaitu campuran bakteri E.tarda dan ekstrak meniran dengan berbagai konsentrasi seperti $1 \mathrm{gr} ; 1 \mathrm{gr} / \mathrm{ml} ; 0,5 \mathrm{gr} / \mathrm{ml} ; 0,25 \mathrm{gr} / \mathrm{ml} ; 0,125$ $\mathrm{gr} / \mathrm{ml} ; 0,0625 \mathrm{gr} / \mathrm{ml}, 0,0313 \mathrm{gr} / \mathrm{ml} ; 0,0156 \mathrm{gr} / \mathrm{ml}$; $0,0078 \mathrm{gr} / \mathrm{ml} ; 0,0039 \mathrm{gr} / \mathrm{ml}$. Perubahan warna pada uji MIC yang merupakan percampuran antara bakteri dan ekstrak meniran disajikan pada gambar 1 .

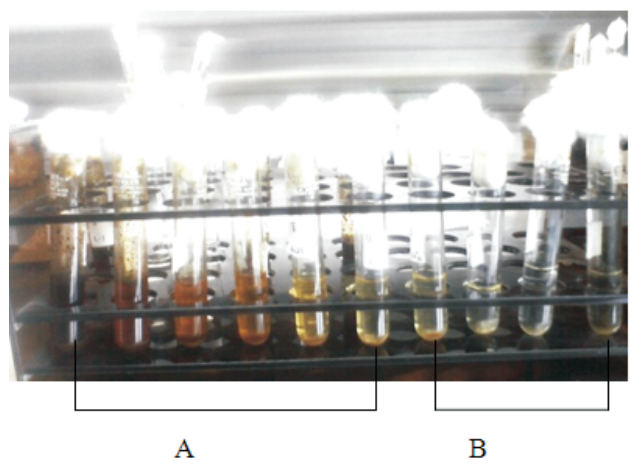

Gambar 1. Perubahan Warna Hasil Uji MIC

Keterangan :

A : tabung reaksi yang menunjukkan perubahan warna semakin kekanan semakin jernih,

B : perubahan warna tabung reaksi yang menunjukkan warna jernih
Tabel 2. Hasil Uji MIC pada bakteri E. Tarda

\begin{tabular}{lll}
\hline \multicolumn{2}{c}{ Konsentrasi } & \multicolumn{1}{c}{ Perubahan Warna } \\
\hline 1 & $\mathrm{gr} / \mathrm{ml}$ & Keruh (bakteri terhambat) \\
1 & $\mathrm{gr} / \mathrm{ml}$ & Keruh (bakteri terhambat) \\
0,5 & $\mathrm{gr} / \mathrm{ml}$ & Keruh (bakteri terhambat) \\
0,25 & $\mathrm{gr} / \mathrm{ml}$ & Keruh (bakteri terhambat) \\
0,125 & $\mathrm{gr} / \mathrm{ml}$ & Keruh (bakteri terhambat) \\
$0,0625 \mathrm{gr} / \mathrm{ml}$ & Keruh (bakteri terhambat) \\
$0,0313 \mathrm{gr} / \mathrm{ml}$ & Jernih (bakteri tidak terhambat) \\
$0,0156 \mathrm{gr} / \mathrm{ml}$ & Jernih (bakteri tidak terhambat) \\
$0,0078 \mathrm{gr} / \mathrm{ml}$ & Jernih (bakteri tidak terhambat) \\
$0,0039 \mathrm{gr} / \mathrm{ml}$ & Jernih (bakteri tidak terhambat) \\
Kontrol (+) & Jernih (bakteri tidak terhambat) \\
Kontrol (-) & Keruh (bakteri terhambat) \\
\hline
\end{tabular}

Pada hasil uji MIC menujukkan bahwa konsentrasi $1 \mathrm{gr} / \mathrm{ml}$ hingga konsentrasi $0,0625 \mathrm{gr} / \mathrm{ml}$ perubahan warna menjadi keruh hal ini menunjukkan bahwa bakteri terhambat. Pada konsentrasi 0,0313 gr/ml hingga konsentrsi $0,0039 \mathrm{gr} / \mathrm{ml}$ perubahan warna jernih hal ini menunjukkan bakteri tidak terhambat. Perubahan warna pada uji MIC tidak dapat dijadikan patokkan terhambat atau tidaknya bakteri, oleh karena itu dilanjutkan uji MBC.

\section{Hasil Uji MBC (Minimum Bactericidial Concentration)}

Pengujian MBC merupakan lanjutan pada pengujian MIC, pengujian MBC membuktikan akan pengujian MIC yang dilakukkan secara visual. Pada metode MBC dilakukan goresan pada media TSA ( Trypstic Soy Agar) dengan hasil yang dapat disajikkan pada Tabel 3. 
Pada konsentrasi 1 gr hingga konsentrasi $0,0313 \mathrm{gr} / \mathrm{ml}$ bakteri tidak tumbuh seperti yang terlihat pada Gambar 1. Konsentrasi 0,0156gr/ml sampai dengan konsentrasi $0,0039 \mathrm{gr} / \mathrm{ml}$ terlihat pertumbuhan bakteri pada media TSA (Trypatic Soy Agar) seperti yang terlihat pada Gambar 2.

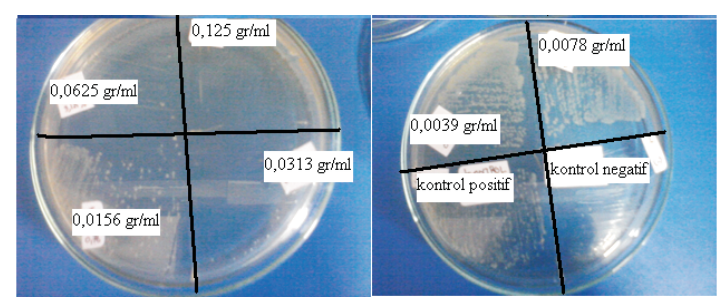

A

B

Gambar 2. Hasil Uji MBC Dengan Konsentrasi $1 \mathrm{gr}-0,0313 \mathrm{gr} / \mathrm{ml}$

Keterangan :

A : tidak terdapat pertumbuhan bakteri

B : tidak terdapat bakteri kecuali konsentrasi $0,0156 \mathrm{gr} / \mathrm{ml}$

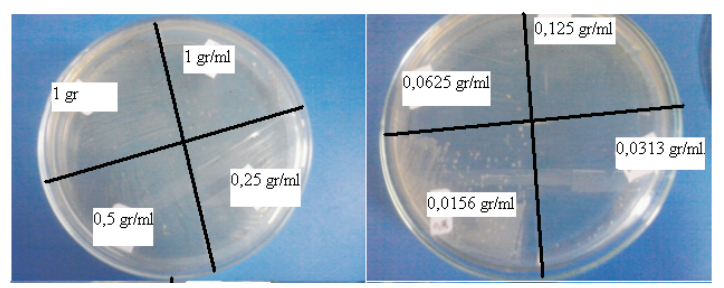

A

B

Gambar 3. Hasil Uji MBC Dengan Konsentrasi $0,156 \mathrm{gr} / \mathrm{ml}-0,039 \mathrm{gr} / \mathrm{ml}$

Keterangan :

A : tidak terdapat bakteri kecuali $0,0156 \mathrm{gr} / \mathrm{ml}$

B : tidak terdapat pertumbuhan bakteri kecuali kontrol negatif

Tabel 3. Hasil Uji MBC pada bakteri E. Tarda

\begin{tabular}{lll}
\hline \multicolumn{2}{c}{ Konsentrasi } & \multicolumn{1}{c}{ Perubahan Warna } \\
\hline 1 & $\mathrm{gr} / \mathrm{ml}$ & Bakteri tidak tumbuh \\
1 & $\mathrm{gr} / \mathrm{ml}$ & Bakteri tidak tumbuh \\
0,5 & $\mathrm{gr} / \mathrm{ml}$ & Bakteri tidak tumbuh \\
0,25 & $\mathrm{gr} / \mathrm{ml}$ & Bakteri tidak tumbuh \\
$0,125 \mathrm{gr} / \mathrm{ml}$ & Bakteri tidak tumbuh \\
$0,0625 \mathrm{gr} / \mathrm{ml}$ & Bakteri tidak tumbuh \\
$0,0313 \mathrm{gr} / \mathrm{ml}$ & Bakteri tidak tumbuh \\
$0,0156 \mathrm{gr} / \mathrm{ml}$ & Bakteri tumbuh \\
$0,0078 \mathrm{gr} / \mathrm{ml}$ & Bakteri tumbuh \\
$0,0039 \mathrm{gr} / \mathrm{ml}$ & Bakteri tumbuh \\
Kontrol $(+)$ & Bakteri tumbuh \\
Kontrol $(-)$ & Bakteri tidak tumbuh \\
\hline
\end{tabular}

Pada konsentrasi 1 gr hingga konsentrasi $0,0313 \mathrm{gr} / \mathrm{ml}$ bakteri tidak tumbuh. Konsentrasi $0,0156 \mathrm{gr} / \mathrm{ml}$ sampai dengan konsentrasi $0,0039 \mathrm{gr} / \mathrm{ml}$ terlihat pertumbuhan bakteri pada media TSA (Trypatic Soy Agar). Pada kontrol positif (+) yang berisi $1 \mathrm{ml}$ aquades dan $1 \mathrm{ml}$ bakteri sehingga terlihat bakteri yang tumbuh sedangkan pada kontrol negatif (-) yang berisi $1 \mathrm{gr}$ ekstrak meniran dan $1 \mathrm{ml}$ aqudes tidak terdapat aktivitas pertumbuhan bakteri.

Berdasarkan hasil penelitian dengan memperhatikan tingkat pertumbuhan bakteri, dapat diketahui bahwa konsentrasi terendah ekstrak meniran yaitu $0,0156 \mathrm{gr} / \mathrm{ml}$ dapat menghambat bakteri E.tarda. Sedangkan konsentrasi meniran yang dapat membunuh bakteri E.tarda yaitu pada konsentrasi 0,0313 gr/ml. Pada uji MIC menunjukkan bahwa pada konsentrasi 1 gr hingga konsentrsi $0,0625 \mathrm{gr} / \mathrm{ml}$ tabung reaksi terlihat keruh, sedangkan pada konsentrasi $0,0313 \mathrm{gr} / \mathrm{ml}$ hingga konsentrasi $0,0039 \mathrm{gr} / \mathrm{ml}$ tabung reaksi terlihat warna jernih.

Pada uji MBC daya antibakteri dapat diketahui secara pasti pada saat setelah dilakukan penanaman pada media TSA. Pada hasil uji MBC menunjukkan bahwa konsentrasi 0,0156 gr/ml sudah terdapat pertumbuhan bakteri tetapi jumlahnya sedikit, hal ini menunjukkan bahwa ekstrak meniran dapat menghambat pertumbuhan E.tarda. Pada konsentrasi 1gr hingga 0,0313 gr/ml tidak terdapat pertumbuhan bakteri hal ini berarti ekstrak meniran dapat membunuh pertumbuhan E.tarda dan pada konsentrasi $0,0078 \mathrm{gr} / \mathrm{ml}$ hingga $0,0039 \mathrm{gr} / \mathrm{ml}$ terdapat banyak sekali pertumbuhan bakteri yang artinya ekstrak meniran tidak dapat membunuh pertumbuhan bakteri E.tarda.

Tumbuh atau tidaknya bakteri pada setiap konsentrasi dapat disebabkan karena pada setiap konsentrasi mengandung kadar antibakteri yang berbeda, semakin encer pada uji MIC jumlah pelarut lebih besar daripada jumlah ekstrak tanaman meniran (Sudewo, 2007). Tanaman meniran dapat digunakan sebagai antibakteri karena pada meniran mengandung bahan-bahan antibakteri seperti flavonoid (Evans, 1989), fenol,tannin (Wijayakusuma dkk., 1996) dan alkaloid (Berghe, 1991).

Antibakteri tannin dapat membunuh pertumbuhan bakteri karena tannin mempunyai daya toksisitas. Daya toksisitas pada tannin akan menyebabkan membran sel bakteri mengkerutkan membran sitoplasma yang mengakibatkan perubahan permiabilitas sel (Ajizah, 2004). Membran 
sitoplasma merupakan tempat keluar masuknya makanan dan memelihara integritas komponenkomponen sel, sehingga apabila membran sel bakteri rusak akibatnya bakteri akan mati (Berghe, 1991). Tanin juga mempunyai daya antibakteri dengan cara mempresipitasi protein (Ewing and Edward, 1973).

Selain sebagai antibakteri Flavonoid juga dapat berfungsi sebagai anti inflamasi, antivirus dan antiparasit, juga dapat sebagai anti alergi (Dwidjoseputro, 1994). Zat antibakteri pada flavonoid bekerja dengan cara menghambat pertumbuhan pada bakteri dengan merusak dinding sel dan membran sitoplasma. Selain itu efek flavonoid juga dapat mencegah pembelahan bakteri sehingga bakteri tidak dapat berkembang biak (Evans, 1989) dan membentuk senyawa kompleks terhadap protein extraseluler yang mengganggu integritas membran sel bakteri (Tuti, 1997).

Alkaloid bekerja sebagai antibakteri dengan cara merusak komponen penyusun peptidoglikan pada sel bakteri, sehingga lapisan dinding sel tidak terbentuk secara utuh dan menyebabkan kematian sel tersebut (Heyne, 1987). Pada senyawa fenol dapat menyebabkan denaturasi protein (Masduki, 1996) pada yang akan menyebabkan sel membran mengalami lisis (Robinson, 1995).

Semakin tinggi konsentrasi antibakteri yang digunakan maka akan semakin cepat bakteri mati, tetapi penggunaan konsentrasi yang tinggi dalam pengobatan juga tidak dianjurkan karena dapat menimbulkan resistensi dan kurang ekonomis dalam pemakaiannya (Michael and Chan, 1988). Hasil penelitian tentang efektifitas ekstrak meniran terhadap E.tarda dapat dibuktikan bahwa ekstrak meniran efektif sebagai obat antibakteri yang aman karena bersifat ramah lingkungan dan tidak menimbulkan pencemaran pada lingkungan ikan.

\section{Kesimpulan}

Berdasarkan hasil penelitian ini, dapat disimpulkan bahwa ekstrak meniran dapat dibuktikan sebagai antibakteri E.tarda dengan konsentrasi terbaik yaitu $0,0313 \mathrm{gr} / \mathrm{ml}$. Pada konsentrasi 0,0313 gr/ml sebagai konsentrasi terbaik karena konsentrasi tersebut merupakan konsentrasi terendah dan tidak terdapat pertumbuhan bakteri.

Perlu dilakukan penelitian lanjutan untuk mengetahui efektifitas ekstrak meniran pada jenis bakteri gram negatif lain dan dilakukan secara in vivo. Pada penyiapan ekstrak perlu diperhatikan tingkat kekeringan bahan herbal untuk mendapatkan ekstrak yang baik.

\section{Daftar Pustaka}

Afrianto, E dan E. Liviawaty. 1992. Pengendalian Hama dan Penyakit Ikan. Penerbit Kanisius. Yogyakarta.

Ajizah, A. 2004. Sensitivitas Salmonella Typhimurium Terhadap Ekstrak Daun Psidium Guajava L. Bioscientiae, Vol. 1, No. $1: 31-8$.

Berghe, V. 1991. Screening Methods For Bacterial Antiviral Agents For Higher Plants. Harcource Brace Jauvanovich Publ. London.

Dwidjoseputro, D. 1994. Dasar-Dasar Mikrobiologi. Djambatan. Jakarta.

Evans, W. C. 1989. Trease and Evans Pharmacognosy Basic Of Therapeutics. $4^{\text {th }}$ ed. W.B. Sanders. Bailliere Tindall. London. $420 \mathrm{P}$.

Ewing, H. W. and P. R. Edward. 1973. Identification Of Enterobactericeae By Biochemichal Reaction. Burgess Publishing Co. Mineapolis. 61-89 P.

Health Agency. 2001. Edwardsiella tarda. Material Safety Data Sheets (MSDS). Public Health Agency of Canada. Jan.

Heyne, K. 1987. Tanaman Berguna Indonesia, Jilid II. Yayasan Sauna Wana Jaya. Jakarta. Halaman 1138-114.

Leotta, G., and V. Germán. 2009. Prevalence of E.tarda in Antarctic wildlife Polar Biology. Volume 35. 809-812 P.

Masduki, I. 1996. Efek Antibakteri Ekstrak Biji Pinang (Areca catechu) terhadap S. aureus dan Bakteri. Cermin Dunia Kedokteran 109 . Halaman 214.

Michael, J. P and E. C. S. Chan. 1988. Dasar-Dasar Mikrobiologi. Universitas Indanesia Press. Jakarta. Halaman 808-813.

Rao, P. S., Y. Yamada., Y . P. Tan., and K. Y. Leung. 2004. Use of proteomics to identify novel virulence determinants that are required for Edwardsiella tarda pathogenesis. Mol Microbiol. 573-86 P.

Robinson, T. 1995. Senyawa Organik Tanaman Tingkat Tinggi. ITB. Bandung.

Sidik dan A. Subarnas. 1993. Phyllanthus niruri L.; Kimia, Farmakologi dan Penggunaannya Dalam Obat Tradisional. Proseding Seminar Meniran dan Kedawung 13-14 Agustus 1993. Surabaya. 
Sudewo, B. 2007. Basmi Penyakit dengan Sirih Merah, PT Agromedia Pustaka, Jakarta.

Tuti, D. S. 1997. Isolasi and Identifikasi Triterpinoid dari Batang Meniran. Skripsi. FF-UA. Surabaya.
Wijayakusuma, H., S. Dalimartha., A. S. Wirian., B. Wibowo. 1996. Tanaman Berkhasiat Obat Di Indonesia. Edisi I. pustaka Kartini. Jakarta.Halaman 66-67. 